\title{
AKIBAT HUKUM DEBITOR WANPRESTASI TERHADAP PERJANJIAN HAK PATEN SEBAGAI OBJEK JAMINAN FIDUSIA
}

\author{
Dian Herlambang, Yoga Catur Wicaksono, \\ Muhammad Ridho Wijaya, Yudhistira Ardana \\ Fakultas Ekonomi dan Bisnis, Institut Informatika dan Bisnis Darmajaya \\ Fakultas Hukum Universitas Lampung, STMIK Pringsewu. \\ dianherlambang03@gmail.com,yogacaturwicaksono11@gmail.com, \\ ridhowijayaa@gmail.com, ardanayudhistira@gmail.com
}

\begin{abstract}
Abstrak
Pelaku Ekonomi dalam rangka pengembangan usaha sebagai pemilik atau pemegang hak paten dapat mengakses kredit dari lembaga keuangan dengan paten sebagai objek jaminan fidusia. Sehingga hak paten yang berdasarkan undang-undang, melainkan lahir karena harus diperjanjkan terlebih dahulu antara lembaga jaminan fidusia selaku kreditor dengan inventor sebagai debitor. Permasalahan dalam penelitian ini adalah mengapa hak paten dapat dijadikan objek jaminan fidusia dan bagaimanakan akibat hukum bagi pihak debitur yang melakukan wanprestasi. Penelitian ini merupakan penelitian hukum normatif. Dalam penelitian ini, yang dikaji adalah ketentuan hukum positif mengenai hak paten yaitu Undang-Undang Nomor 13 Tahun 2016 tentang Paten dan Undang-Undang Nomor 42 Tahun 1999 tentang Jaminan Fidusia. Tipe penelitian yang digunakan adalah deskriptif dengan pendekatan masalah yang akan dilakukan secara yuridis normatif. Hak paten bisa dijadikan jaminan hutang dengan menggunakan lembaga jaminan fidusia karena hak paten yang merupakan bagian dari hak kekayaan intelektual dimana hak paten memiliki prinsip ekonomi yang akan memberikan keuntungan ekonomi kepada pemilik hak paten. Hak paten diklasifikasikan kedalam benda bergerak yang tidak berwujud. Akibat hukum debitur yang melakukan wanprestasi akan menimbulkan kegiatan eksekusi jaminan fidusia. Eksekusi jaminan fidusia merupakan penyitaan dan penjualan benda yang menjadi objek jaminan fidusia. Akibat dari penjualan objek fidusia ini yang berupa hak paten maka dari pihak kreditur hilangnya piutang kepada debitur yang artinya hutang debitur telah lunas, kemudian dari pihak debitur hilangnya hak-hak atas paten yang sebelumnya dia miliki.
\end{abstract}

\section{Kata Kunci : Hak Paten, Jaminan, Fidusia}

\begin{abstract}
Economic actors in the framework of developing a business as owner or patent holder can access credit from financial institutions with patents as objects of fiduciary institution. So that patents are based on the law, but were born because they had to be advance in advance between the fiduciary guarantee institution as the creditor and the inventor as the debtor The problem in this study is why patents can be used as fiduciary collateral objects and how the legal consequences for debtors who commit defaults. This research is a normative legal research. In this study, what is examined is the positive legal provisions regarding patent rights, namely Law Number 13 of 2016 concerning Patents and Law Number 42 of 1999 concerning Fiduciary Guarantees. This type of research used is descriptive with a problem approach that will be conducted normatively juridical. Patents can be used as collateral for debt by using fiduciary security institutions because patents are part of intellectual property rights where patents have economic principles that
\end{abstract}


will provide economic benefits to the patent owner. Patents are classified as immovable property. The legal consequences of debtors who commit default will lead to fiduciary guarantee execution activities. Execution of fiduciary collateral is confiscation and sale of objects which are subject to fiduciary collateral. As a result of the sale of this fiduciary object in the form of a patent, the creditors lose their debts to the debtor, which means the debtor's debt has been paid off, then from the debtor's loss of patent rights he previously had such as.

\section{Keywords: Patent, Collateral, Fiduciary}

\section{Pendahuluan}

\section{A. Latar Belakang}

Pembangunan dalam sektor ekonomi nasional merupakan salah satu upaya untuk mencapai masyarakat yang adil dan makmur sesuai dengan pancasila dan UndangUndang Dasar 1945. hal ini dapat dilakukan dengan memelihara dan meneruskan kegiatan pembangunan yang berkesinambungan. Kesinambungan tersebut dapat dilihat dari terjalinnya kerjasama yang baik antara pelaku-pelaku pembangunan, baik dari pemerintah ataupun masyarakat, perseorangan maupun badan hukum. Selain memerlukan kerjasama yang baik, para pelaku pembangunan pastinya memerlukan dana yang besar, dimana dana yang dibutuhkan ini untuk memenuhi kebutuhan dalam meningkatkan kegiatan pembangunan ${ }^{1}$.

Akibat dari besarnya dana yang dibutuhkan, maka dalam praktek hukum dikenal bentuk-bentuk lembaga yang dapat memberikan kebutuhan para pihak dalam hal pendanaan. Akan tetapi, pendanaan yang dimaksud bukanlah sebuah pemberian dana secara cuma-cuma namun dalam hal pendanaan ini pihak-pihak yang membutuhkan dana harus memberikan jaminan kebendaan yang dimiliki atau dikuasai. Lembaga penjaminan yang sudah dikenal baik dalam negara dengan system hukum common law maupun system hukum civil law adalah pand maupun hipotik, namun seiring dengan berkembangnya moderenisasi dan globalisasi maka bentuk lembaga jaminan

\footnotetext{
${ }^{1}$ Kashadi Purwahid Patrik, Hukum Jaminan Edisi Revisi dengan UUHT, Semarang : Fakultas Hukum Universitas Diponegoro, 2005, hlm 33.
}

tersebut dianggap masih kurang sehingga muncullah lembaga jaminan lain yaitu lembaga jaminan fidusia.

Jaminan Fidusia lahir untuk melengkapi kelemahan dari adanya jaminan gadai. ${ }^{2}$ Kelemahan dari gadai terlihat pada objek jaminannya yang berada di tangan penerima gadai. Apabila objek tersebut diserahkan kepada penerima gadai, pemberi gadai tidak dapat menggunakan objek tersebut. Padahal objek yang dijaminkan itu sangat penting dan berguna bagi pemberi gadai dalam menajalankan usahanya. Beda halnya dengan jaminan fidusia, jaminan fidusia adalah suatu jaminan hutang yang bersifat kebendaan yang pada prinsipnya memberikan benda bergerak sebagai jaminannya dengan memberikan penguasaan atas benda yang menjadi objek jaminan tersebut kepada debitur. Tetapi pengalihan hak milik atas benda objek jaminan tersebut kepada kreditur kemudian pihak kreditur menyerahkan penguasaan benda yang menjadi objek jaminan kepada debiturnya secara kepercayaan (fiduciary). ${ }^{3}$

Berdasarkan Undang-Undang Jaminan Fidusia, Objek pada jaminan fidusia diberikan pengertian yang sangat luas yang tidak hanya benda bergerak yang berwujup

${ }^{2}$ Sri Mulyani, realitas pengakuan hukum terhadap hak atas merek sebagai jaminan fidusia pada praktik perbankan di Indonesia, Hukum dan Dinamika Masyarakat Vol.11 No.2 April 2014, hlm 136.

${ }^{3}$ Sri Soedewi Mascjhun Sofwan, Beberapa Masalah Pelaksanaan Lembaga Jaminan Fidusia di Dalam praktik dan Perkembangan di Indonesia, Yogyakarta : Fakultas Hukum UGM, 1980, hlm 15. 
ataupun tidak berwujud. Melainkan benda tidak bergerak yang tidak dapat dibebani dengan hak tanggungan.

Undang-Undang ini memberikan kesempatan kepada setiap pelaku usaha untuk dapat melakukan kredit dengan menjaminkan benda yang dimiliki walaupun benda tersebut tidak berwujud seperti Hak Kekayaan Intelektual.

Banyak sekali negara-negara memanfaatkan Hak Kekayaan Intelektual untuk mendapatkan keuntungan ekonomi dalam jumlah yang besar. ${ }^{4}$ Keuntungan ekonomi yang dimaksud itu disebabkan oleh HKI dapat dijual, dilisensikan, serta digunakan sebagai objek jaminan hutang.

System hukum yang berkembang di Indonesia didalam bidang HKI sangat dipengaruhi oleh hukum internasional dan juga oleh hukum negara-negara lain. Hal ini disebabkan karena system hukum internasional yang mengatur mengenai hak kekayaan intelektual lebih duluan lahir dan berkembang secara dinamis dan progresif dibandingkan dengan hukum nasional. ${ }^{5}$

Hak Kekayaan Intelektual (HKI) adalah hak yang berasal dari hasil kreasi suatu kemampuan daya pikir manusia yang diekspresikan kepada khalayak umum dalam berbagai bentuknya, yang memiliki manfaat serta menunjang bagi kehidupan manusia. ${ }^{6}$ Pada intinya HKI adalah suatu hak untuk menikmati secara ekonomis hasil dari suatu kreativitas intelektual. Objek yang diatur dalam HKI adalah karya-karya yang timbul karena kemampuan intelektual manusia. Secara Konvensional HKI dibagi dua, yaitu Hak Cipta dan Hak Kekayaan Industri yang terbagi atas berbagai bidang

4 Utomo Suryo Tomi, Hak Kekayaan Intelektual di Era Global, Yogyakarta : Graha Ilmu, 2010, hlm 41.

5 Syafrinaldi, Sistem Hukum Hak Kekayaan Intelektual, Respublika, Vol.4 No. 1, 2004, hlm 78.

6 Kholis Roisah, Kebijakan Hukum "Tranerability" Terhadap Perlindungan Hak Kekayaan Intelektual Di Indonesia", Jurnal Law Reform, Vol.11, No.2, 2015, hlm 242
HKI seperti Paten, Merek dan Indikasi Geografis, Rahasia Dagang, Desain Industri, Desain Tata Letak Sirkuit Terpadu, dan Varietas Tanaman. ${ }^{7}$

Hak Paten adalah hak yang diberikan oleh pemerintah dan bersifat ekslusif. Hak ekslusif dari pemegang hak paten adalah produksi dari barang yang dipatenkan (manufacturing), penggunaan (using) dan penjualan (selling) dari barang tersebut. Perbuatan-perbuatan yang berkaitan dengan penjualan barang seperti mengimpor dan menyimpan (stocking). ${ }^{8}$ Paten dalam pengertian hukum adalah hak khusus yang diberikan berdasarkan Undang-Undang oleh pemerintah kepada orang atau badan hukum yang menghasilkan suatu penemuan (invention) dibidang teknologi.

Dalam rangka pengembangan usaha, pelaku ekonomi sebagai pemilik atau pemegang hak paten dapat mengakses kredit dari lembaga keuangan dengan paten sebagai objek jaminan fidusia. Hak Paten dapat dijadikan sebagai objek jaminan fidusia. ${ }^{9}$ Hal ini bearti, lembaga keuangan baik bank maupun bukan bank akan menerima hak paten sebagai jaminan hutang. Sehingga hak paten yang menjadi objek jaminan fidusia bukan merupakan hak jaminan yang lahir berdasarkan undang-undang, melainkan lahir karena harus diperjanjikan terlebih dahulu antara Lembaga Jaminan Fidusia selaku Kreditor dengan nasabah sebagai debitor. Sehingga bertolak dari uraian latar belakang maka penulis ingin menganalisis lebih lanjut mengenai permasalahan dan menyusunnya dalam sebuah karya tulis yang berjudul "Hak Paten Sebagai Objek Jaminan Fidusia".

7 Rindia Fanny Kusumaningtyas, perkembangan hukum jaminan fidusia berkaitan dengan hak cipta sebagai objek jaminan fidusia, Pandecta Vol.11, No.1, Juni 2016, hlm 97.

8 Mastur, perlindungan hukum kekayaan intelektual dibidang paten, QISTI, Vol.6, No.1, Januari 2012, hlm 67.

9 Pasal 108 ayat 1, Undang-Undang Nomor 13 Tahun 2016 Tentang Paten 


\section{B. Rumusan Masalah}

1. Mengapa Hak Paten Dapat Dijadikan Objek Jaminan Fidusia?

2. Bagaimana Akibat Hukum Bagi Pihak Debitor yang Melakukan Wanprestasi?

\section{Tujuan}

1. Untuk mengetahui, memahami dan menganalisa alasan hak paten dapat dijadikan sebagai objek jaminan fidusia.

2. Untuk mengetahui, memahami dan menganalisa akibat hukum bagi pihak debitor yang melakukan wanprestasi.

\section{Metode Penulisan}

Penelitian ini merupakan penelitian hukum normatif. Dalam penelitian ini, yang dikaji adalah ketentuan hukum positif mengenai Hak Paten Yaitu Undang-Undang Nomor 13 Tahun 2016 tentang Paten dan Undang-Undang Nomor 42 Tahun 1999 tentang Jaminan Fidusia. Tipe penelitian yang digunakan adalah deskriptif. Sesuai dengan masalah yang akan dibahas maka pendekatan masalah yang akan dilakukan secara yuridis normatif.

\section{Pembahasan}

A. Kerangka Konsepsional.

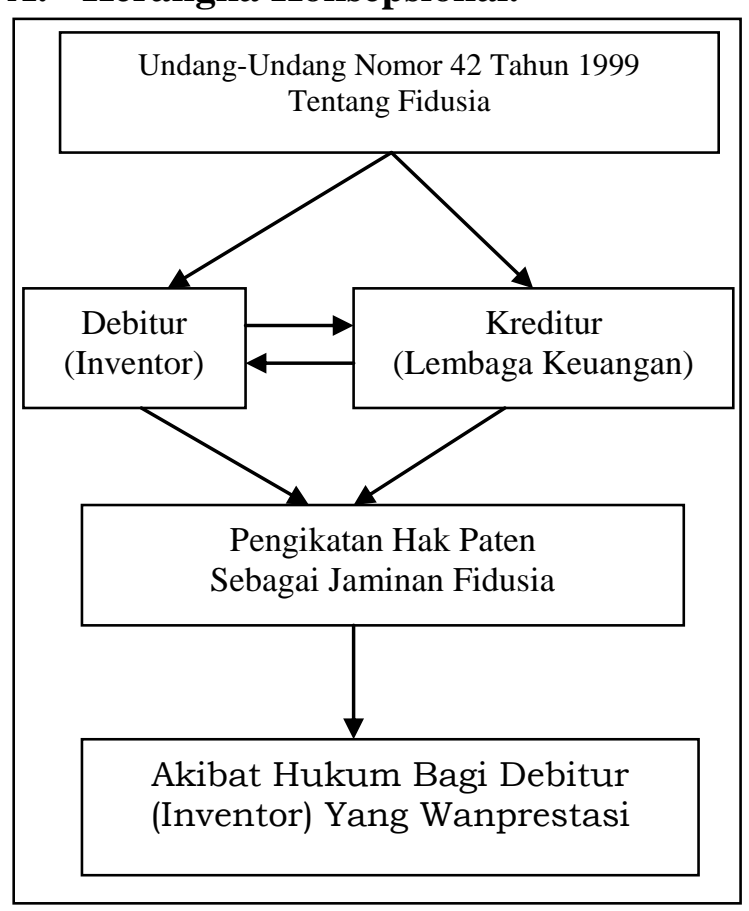

Berdasarkan skema di atas dapat dijelaskan bahwa:

Jaminan fidusia merupakan jaminan yang lebih berdasarkan kepercayaan. Oleh karena didasarkan kepercayaan hubungan hukum yang terjadi antara debitur (pemberi fidusia) dan kreditur (penerima fidusia) merupakan hubungan hukum berdasarkan kepercayaan. Hal ini dapat dilihat dari Undang-Undang Nomor 42 Tahun 1999 Tentang Jaminan Fidusia yang memberi pengertian mengenai jaminan fidusia yaitu pengalihan hak kepemilikan suatu benda atas dasar kepercayaan dengan ketentuan bahwa benda yang hak kepemilikannya dialihkan tetap dalam penguasaan pemilik benda.

Pihak Debitur dalam hal ini adalah inventor yang ingin mendapatkan tambahan dana dengan cara menjaminkan patennya kepada pihak kreditur dalam hal ini lembaga Keuangan. membuat suatu hubungan hukum antara para pihak agar tercapainya kegiatan pinjam meminjam ini. hubungan hukum yang terjadi antara inventor dengan lembaga jaminan ditimbulkan oleh adanya pengikatan atau perjanjian yang dibuat oleh para pihak untuk mencapai kesepakatan dalam kegiatan pinjam-meminjam.

Dalam membuat suatu perjanjian terdapat proses pembuatan perjanjian harus dilakukan sesuai dengan syarat dan prosedur yang berlaku sampai mencapai kata sepakat antar pihak. Sehingga, menimbulkan hak dan kewajiban yang harus dipenuhi oleh para pihak. Biasanya dalam kegiatan ini pihak debitur yang sering kali tidak memenuhi kewajibannya atau wanprestasi sebagai debitur (inventor), maka akan menimbulkan suatu akibat hukum bagi pihak yang melakukan wanprestasi.

\section{B. Hak Paten Sebagai Objek Jaminan Fidusia.}

1. Hak Paten Sebagai Bagian Hak Kekayaan Intelektual

Hak Paten adalah bagian dari Hak Kekayaan Intelektual, yang termasuk dalam kategori hak milik perindustrian 
(Industrial Property right). ${ }^{10}$

Paten adalah hak ekslusif yang diberikan oleh negara kepada inventor atas hasil invensinya dibidang teknologi untuk jangka waktu tertentu melaksanakan sendiri invensi tersebut atau memberikan persetujuan kepada pihak lain untuk melaksanakannya.

Intellectual rights are legal rights, whick in virtue of law provide a lot of legal possibilities and can be shared among different individuals and legal entities, enjoyed by them, transferred to third parties abd thus be applied in transactions. Especially it concerns an exclusive (Economic) right, which is grated over any object of intellectual property. ${ }^{11}$ Yangmana Hak Kekayaan Intelektual memiliki Prinsip Ekonomi, berasal dari kegiatan kreatif dari daya pikir manusia yang memiliki manfaat serta nilai ekonomi yang akan memberikan keuntungan kepada pemilik hak. ${ }^{12}$

2. Hak paten sebagai benda bergerak tidak berwujud.

Benda bergerak tidak berwujud adalah benda yang timbul dari hubungan tertentu atau hasil perdata. Benda bergerak tidak berwujud adalah hak yang dilekatkan pada suatu benda tertentu yang tidak memiliki wujud. ${ }^{13}$ Menurut R. Subekti suatu benda dihitung sebagai golongan benda yang bergerak karena sifatnya atau karena ditentukan oleh undang-undang. Suatu benda yang bergerak karena sifatnya ialah benda yang tidak tergabung dengan tanah atau dimaksudkan untuk mengikuti

10 Saidin, Aspek Hukum Kekayaan Intelektual, PT Raja Grafindo Persada, Jakarta, 2000, hlm 135.

${ }^{11}$ Valeriy N Lisitsa, Intellectual Property and Intellectual Rights : Issues of Correlation, Journal of Intellectual Property Rights, Vol 23, March-May 2018, hlm 92.

${ }^{12}$ Muhamad Djumhana dan R. Djubaedillah, Hak Milik Intelektual (Sejarah, Teori dan Prakteknya di Indonesia), Bandung : PT Citra Aditya Bakti, 2003, hlm 116.

${ }_{13}$ Pasal 511 angka 3 Kitab Undang-Undang Hukum Perdata tanah atau bangunan. ${ }^{14}$

3. Pembebanan Hak Paten Sebagai

Objek Jaminan Fidusia.

Hak paten merupakan suatu benda bergerak tidak berwujud yang dapat dipindah tangankan. Misalnya dijual, dihibahkan, diwariskan, dan sebagainya. Hal tersebut dapat dilakukan secara tertulis dengan yang bersangkutan dan telah terdaftar didalam daftar umum paten. Pembebanan fidusia harus didasarkan atas perjanjian yang dibuat inventor dengan pemberi kredit atas dasar kebebasan berkontrak. Perjanjian yang telah dibuat oleh para pihak tersebut bersifat mengikat karena itu harus ditaati. Selanjutnya pihak inventor dan pemberi kredit harus mempunyai itikad baik dalam melaksanakan perjanjian sesuai dengan apa yang telah disepakati. ${ }^{15}$ Perjanjian yang dibuat oleh para pihak mengindahkan asasasas hukum perjanjian, asas-asas itu antara lain adalah asas kebebasan berkontrak, asas ini menjadi dasar berlakunya asas konsensual yang mendasari berlakunya asas kekuatan mengikat perjanjian. ${ }^{16}$

Jaminan fidusia merupakan perjanjian tambahan dari perjanjian pokok yang menimbulkan kewajiban bagi para pihak untuk memenuhi suatu prestasi. Kemudian pembebanan benda dengan jaminan fidusia dibuat dengan akta notaries dalam bahasa Indonesia dan merupakan akta jaminan fidusia. Keberadaan dari suatu jaminan sangat penting pada perjanjian pinjam-meminjam agar nantinya tidak merugikan para pihak. Namun berbeda halnya apabila terjadi pembebanan pada hak paten. Sebab, hak paten merupakan suatu benda bergerak yang tidak berwujud yangmana eksistensinya tidak terlihat jelas maka secara kasar bukan benda atau barangnya yang

14 R. Subekti, Pokok-pokok hukum perdata, Jakarta : Intermasa, 2010, hlm 61.

${ }^{15}$ Tan Kamelo, Hukum jaminan fidusia suatu kebutuhan yang didambakan, Bandung : Alumni, 2006, hlm 175.

${ }^{16}$ Ery Agus Priyono, Aspek Keadilan Dalam Kontrak Bisnis Di Indonesia, Jurnal Law Reform, Vol.14, No. 1, 2018, hlm 16. 
menjadi jaminan melainkan hak yang melekat pada jaminan tersebut. ${ }^{17}$

Hak paten yang merupakan bagian dari Hak Kekayaan Intelektual yang memiliki prinsip ekonomis sehingga dapat dijadikan sebagai objek jaminan hutang. Hak paten termasuk sebagai benda bergerak yang tidak berwu-jud ialah benda yang timbul dari hubungan tertentu atau hasil perdata, dengan hak paten termasuknya sebagai benda yang dapat bergerak dan tidak berwujud maka hak paten dapat dijadikan sebagai objek hutang dengan menggunakan lembaga jaminan fidusia dan dengan pembebanan jaminan sesuai dengan undang-undang fidusia yang berlaku.

\section{Akibat Hukum bagi Debitor yang melakukan Wanprestasi.}

Adanya pihak yang melakukan wanprestasi akan menimbulkan kegiatan eksekusi jaminan fidusia. Wanprestasi seorang debitur dapat berupa :

1) Tidak melakukan apa yang disanggupi akan dilakukannya.

2) Melaksanakan apa yang dijanjikan, tetapi tidak sebagaimana dijanjikan.

3) Melakukan apa yang dijanjikan tetapi terlambat.

4) Melakukan sesuatu yang menurut perjanjian tidak boleh dilakukannya ${ }^{18}$

Eksekusi jaminan fidusia adalah penyitaan dan penjualan benda yang menjadi objek jaminan fidusia. Penyebab timbulnya eksekusi jaminan fidusia ini adalah karena debitor todal memenuhi prestasinya tepat pada waktunya kepada pemberi kredit. Terdapat 3 cara eksekusi benda jaminan fidusia, yaitu:

1) Pelaksanaan title eksekutorial, yaitu tulisan yang mengandung pelaksanaan putusan pengadilan yang memberikan

17 Rachmadi Usman, Hukum

kebendaan, Jakarta : Sinar Grafika, 2011, hlm 155.

18 Subekti, Hukum Perjanjian, Jakarta : PT Intermasa, 2001, hlm 45. dasar untuk lelang sita tanpa perantara hakim.

2) Penjualan benda yang menjadi objek jaminan fidusia atas kekuasaan debitur melalui pelelangan umum serta mengambil pelunasan piutangnya dari hasil penjualan.

3) Penjualan dibawah tangan yang berdasarkan kesepakatan pemberi fidusia dan penerima fidusia jika dengan cara demikian dapat diperoleh harga tertinggi yang menguntungkan para pihak. ${ }^{19}$ Jika terjadi wanprestasi maka pihak kreditur dapat meminta debitur untuk menjual patennya, karena pihak debitur lebih ahlinya mengenai paten itu sendiri sehingga debitur tetap dapat melunasi hutangnya, karena jika kreditur menjadi pemilik itu akan beresiko untuk krediut, sebab jika terlalu lama dikuasai dan pihak kreditur tidak paham untuk menjual paten maka paten tersebut expire dan juga adanya biaya pemeliharaan terhadap paten, maka kreditur akan sangat beresiko. Sehingga biasanya kreditur memasukkan klausula pihak de-bitur yang menjual patennya. Akibat dari penjualan objek fidusia ini yang berupa hak paten maka dari pihak kreditur hilangnya piutang kepada debitur yang artinya hutang debitur telah lunas, kemudian dari pihak debitur hilangnya hak-hak atas paten yang sebelumnya dia miliki seperti hak menggunakan, hak mendapatkan royalty, dan sebagainya.

\section{Penutup}

\section{Kesimpulan}

1) Hak paten bisa dijadikan jaminan hutang dengan menggunakan lembaga jaminan fidusia karena hak paten yang merupakan bagian dari Hak Kekayaan Intelektual dimana hak paten memiliki prinsip ekonomi yang akan memberikan keuntungan ekonomi kepada pemilik hak paten. Hak paten merupakan benda bergerak yang tidak berwujud

19 Salim HS, Perkembangan hukum jaminan di Indonesia, Jakarta : PT RajaGrafindo Persada, 2012, hlm 9. 
ialah benda yang timbul dari hubungan tertentu atau hasil perdata.

2) Akibat hukum dari debitur yang melakukan wanprestasi akan menimbulkan kegiatan eksekusi jaminanfidusia. Eksekusi jaminan fidusia merupakan penyitaan dan penjualan benda yang menjadi objek jaminan fidusia. Akibat dari penjualan objek fidusia ini yang berupa hak paten maka dari pihak kreditur hilangnya piutang kepada debitur yang artinya hutang debitur telah lunas, kemudian dari pihak debitur hilangnya hak-hak atas paten yang sebelumnya dia miliki seperti hak menggunakan, hak mendapatkan royalty, dan sebagainya.

\section{DAFTAR PUSTAKA}

\section{A. Peraturan Perundang-Undangan.}

Undang-Undang Nomor 13 Tahun 2016 Tentang Paten.

Kitab Undang-Undang Hukum Perdata

\section{B. Buku}

Djumhana, Muhamad dan R. Djubaedillah, Hak Milik Intelektual (Sejarah, Teori dan Prakteknya di Indonesia), Bandung : PT Citra Aditya Bakti, 2003.

Kamelo, Tan. Hukum jaminan fidusia suatu kebutuhan yang didambakan, Bandung: Alumni, 2006.

Patrik, Kashadi Purwahid. Hukum Jaminan edisi revisi dengan UUHT, Semarang : Fakultas Hukum Universitas Diponegoro, 2005.

R. Subekti. Pokok-pokok hukum perdata, Jakarta : Intermasa, 2010.

Saidin. Aspek Hukum Kekayaan Intelektual, PT Raja Grafindo Persada, Jakarta, 2000.

Salim HS. Perkembangan hukum jaminan di Indonesia, Jakarta : PT RajaGrafindo Persada, 2012.

Sofwan, Sri Soedewi Mascjhun. Beberapa Masalah Pelaksanaan Lembaga Jaminan Fidusia di Dalam praktik dan Perkembangan di Indonesia, Yogyakarta : Fakultas Hukum UGM, 1980.

Subekti. Hukum Perjanjian, Jakarta : PT Intermasa,2001.

Tomi, Utomo Suryo. Hak Kekayaan Intelektual di Era Global, Yogyakarta : Graha Ilmu, 2010.

Usman, Rachmadi. Hukum kebendaan, Jakarta : Sinar Grafika, 2011.

\section{Jurnal}

Ery Agus Priyono, Aspek Keadilan Dalam Kontrak Bisnis Di Indonesia, Jurnal Law Reform, Vol.14, No. 1, 2018.

Kholis Roisah, Kebijakan Hukum "Tranerability" Terhadap Perlindungan Hak Kekayaan Intelektual Di Indonesia”, Jurnal Law Reform, Vol.11, No.2, 2015.

Mastur, perlindungan hukum kekayaan intelektual dibidang paten, QISTI, Vol.6, No.1, Januari 2012.

Rindia Fanny Kusumaningtyas, perkembangan hukum jaminan fidusia berkaitan dengan hak cipta sebagai objek jaminan fidusia, Pandecta Vol.11, No.1, Juni 2016.

Sri Mulyani, realitas pengakuan hukum terhadap hak atas merek sebagai jaminan fidusia pada praktik perbankan di Indonesia, Hukum dan Dinamika Masyarakat Vol.11 No.2 April 2014.

Syafrinaldi, Sistem Hukum Hak Kekayaan Intelektual, Respublika, Vol.4 No.1, 2004. 
Lex Librum : Jurnal Ilmu Hukum, Vol. 7 No.2, Juni 2021, hal. 111-118 